\title{
Nigeria: \\ Face acts in alternative dispute resolution television program. The case of İgbìmo İpètù
}

\author{
Temitope Michael AJAYI \\ Oluwatosin AJAYI \\ Rahidat Temitope FASHINA
}

\begin{abstract}
The concept of alternative dispute resolution (ADR) has largely been under explored from the linguistic lens, particularly in the Nigerian context. This study thus provides a scholarly intervention in this regard. Drawing insights from Brown and Levinson's face theory, four randomly sampled recordings of İgbìmo İpètù, an alternative dispute resolution television programme on the Ekiti State Television (EKTV) in southwestern Nigeria was analysed in this study. Focus was placed on the face acts as well as their

Temitope Michael AJAYI

Department of Linguistics and African Languages, University of Ibadan, Ibadan, Nigeria

E-mail: michealtemitope@yahoo.com

Oluwatosin AJAYI

Department of Linguistics and African Languages, University of Ibadan, Ibadan, Nigeria

E-mail: bussydam01@gmail.com

\section{Rahidat Temitope FASHINA}

Department of Linguistics and African Languages, University of Ibadan, Ibadan, Nigeria

E-mail: fashinarashidat@gmail.com

Conflict Studies Quarterly pragmatic functions in the programme. Findings revealed that bald on-record face-threatening acts (FTA), bald off-record FTA and positive face acts characterized the discursive interaction of participants on the programme. While bald onrecord and off-record FTAs were deployed by the panel to criticize and condemn actions considered unsavory on the part of complainants and the accused, complainants and accused persons deployed on-record FTAs to protest/redress the panel's decisions found unacceptable. The panel used positive face acts as a general principle in the interaction, particularly with cooperative accused persons, while accused persons deployed positive face acts to negotiate the discursive interaction and for face-damage repair.
\end{abstract}

Issue 36, July 2021, pp. 3-21

DOI: $10.24193 / c s q .36 .1$

Published First Online: 05 July /2021
Keywords: Alternative dispute resolution, dispute and media, face acts. 


\section{Introduction}

Ideologically, the Yoruba, like every other group of people particularly in Africa, had their peculiar way of resolving disputes and crises, even long before the importation of the Western system of adjudication in the country. As a peace-loving people (Ajayi, 2017), they understand issues, misunderstandings and grievances not properly and swiftly managed could result in conflicts and chaos in the society. Ajayi and Buhari (2014) note that the adjudication system of the Yoruba thrives on collective wisdom and traditional knowledge of their forebears. To stress the dynamics of the Yoruba adjudication system, Olaoba (2001) reports that age and seniority are reckoned with. In line with this practice, in cases of dispute resolution, elders (considered on the basis of age and seniority) are often being called upon. Such elders usually sit under a tree, listen to the arguments and counter-arguments of the aggrieved parties until a peaceful resolution or conclusion is reached. This practice, although has been pushed to the periphery of the socio-political life of the people, particularly with the adoption of the Western system of resolving issues in the Nigerian space, still holds sway in some core areas of life of the people. And perhaps as a way of preserving this age-long practice of dispute resolution system among the people, virtually all the major television stations (as owned by their respective state governments) across the six states in southwestern Nigeria, predominantly occupied by the people, have one form of alternative dispute resolution program or the other. One of such programs is İgbìmo ìpètù (a committee of settlement or resolution) which presents a platform for people with all manner of civil cases to air their grievances. From observation, one major tool central to achieving the pragmatic goals of such programs is language.

Unfortunately, while many studies have examined (alternative) dispute resolution mainly from the perspective of media, and conflict resolution studies, less attention has been paid to it from the linguistic orientation. Thus, a study of this nature, which focuses on the strategic deployment of linguistic resources in Yoruba alternative dispute resolution system, is apt. This study is significant in that it graphically demonstrates the Yoruba practice of manipulating 'the word' (orọ) in the management of their daily affairs, especially as it relates to dispute management. The specific objectives of this study include finding answers to the following questions:

- What face strategies are used in alternative dispute resolution in Yoruba?,

- What contexts are these strategies deployed?

- What are the pragmatic goals of the use of these face strategies in dispute resolution discourse, as represented by Igbimo ipetu? 


\section{An overview of dispute and alternative dispute resolution discourse and scholarship}

Yates (2003) defines dispute as a claim which is not resolved between two or more parties, and is thus escalated. Black (2009) defines disputes as a controversy or conflict of rights or claims, an assertion of a demand, allegations or claims by another. As noted by Gould (1999), disputes are time consuming and costly to the parties involved, and additionally jeopardize a constructive and amicable relationship between/among them. And one of the srategic means of resolving disputes is the alternative dispute resolution (ADR). The ADR is usually less formal, less expensive and less time-consuming than a trial. The ADR can also give people more opportunity to determine when and how their dispute will be resolved. A typical example of the alternative dispute resolution system is the African Traditional Conflict Resolution system. In resolving disputes, the African traditional values, perceptions and ethics are put to play. Brock-Utne (2001) asserts that "all over Africa, people have deep trust in the alternative dispute resolution" (p. 8). This type of resolution is acceptable by the disputants and their trust in this body has always been the reason for accepting whatever the group resolves. Dispute resolution processes consist of two main classes: those that reserve authority for resolution to the parties themselves and those in which a third party decides the matter (Lucille \& Cavenagh, 1991). As explained by Schwartz (n.d), the ADR includes a number of conflict resolution processes such as unassisted negotiation, mediation (otherwise called facilitated negotiation) fact-finding, early neutral evaluation, dispute review boards, standing neutrals, summary jury trial, mini-trial and arbitration. Essentially, these processes help minimize cost, the time involved, the uncertainty of a decision by a judge or jury, as well as ensure privacy and business relationships. It is considered more flexible than litigation.

Within the Nigerian context, a number of studies, particularly in the fields of sociology, law, and communications have explored different dimensions of ADR in Nigeria. Some of these studies include Orji (2012), Oni-Ojo and Roland-Otaru (2013), Ige (2017), Nwazi (2017), Matawal (2018), Uzuegbunam and Omenugha (2018), and Iseh (2020), among others. For instance, Orji (2012), from the lens of the nexus between technology and law, explores the possibilities of deploying the Information Communication Technology tools for dispute resolution, as well as its challenges. Orji claims the deployment of ICT platforms serves as an effective means of dispute resolution which should be extensively keyed in to in the Nigerian context. In the spirit of the arguments of Orji (2012), Oni-Ojo and Roland-Otaru (2013) emphasize the need to embrace the ADR in place of the litigative options which have not really achieved much in addressing the many socio-religious crises and conflicts that have defined the contemporary African space in general and Nigeria in particular. Ige (2017), within the legal framework, explores the contextual dynamics to the workings of alternative dispute resolution, employment relations and 
collective conciliation in Nigeria, with particular emphasis on the roles of different stakeholders such as trade unions and employers in reconciliatory processes. The work reveals the institutional weaknesses of state machinery constitute a major problem to conciliatory process within the Nigerian space. Nwazi (2017) examines the use and effectiveness of alternative dispute resolution in the resolution of environmental-related issues/disputes in the Niger Delta region of Nigeria. Nwazi notes that the ADR has helped address the issues of delays, high costs, and technicality associated with litigation in the region. Matawal (2018), and Uzuegbunam and Omenugha (2018), coming from the angle of communications and media studies, reiterate the role of the media in the resolution of disputes and conflicts in the Nigerian society. To a large extent, both studies accentuate the fact that the media has not really lived up to expectation in the management and resolution of disputes and crises in Nigeria.

Away from the domain of legal and communications studies that have extensively explored the phenomenon of ADR in Nigeria, few linguistic studies are equally worthy of mention in this study. For instance, Ogwuche (2016), Oyedele (2016) and Ajayi (2017) have examined three different dispute resolution television programs (Ijoko Ojogbon, Mogbejomide, and Sodaabe) on television stations in Ondo, Lagos, and Oyo states, respectively. The works, although from three different theoretical perspectives, thematically focus and give insights into how participants in Yoruba dispute resolution interactions are guided by the principles of omoluabi, a phenomenon that is very central to the Yoruba value system. While it could be argued that these works have essentially engaged the ADR in the media from the linguistic lens, it is important to add that the current study, which sources data from another Yoruba dispute resolution television programme, provides a fresh and additional perspective to the study of media and dispute resolution in Nigeria. Besides, it is a further engagement of the face/politeness theory of Brown and Levinson which has been heavily critiqued, criticized and commended in linguistic scholarship.

\section{Theoretical orientation:}

\section{Brown and Levinson's face (acts) theory}

Although the notion of face was introduced to linguistic studies on interactions by Goffman (1967), the notion has been largely theorized and popularised by Brown and Levinson $(1978,1987)$. It has become the most influential theory on politeness (Sadeghoghli \& Niroomand, 2016), and has equally been vital in the study of speech acts (Hobbs, 2003; Ji, 2000). As reported by Sadeghoghli and Niroomand (2016), three elements are central to Brown and Levinson's face theory, namely face, face-threatening acts (FTAs) and politeness strategies. Accordingly, face refers to the public self-image that every member (of a society) wants to claim for himself (Brown \& Levinson, 1978, 1987). Thus, individual members of the society have two main face desires/wants: the desire to have their freedom being respected; have their claim to personal territories 
being acknowledged, and generally the desire to be free from imposition. This is called the negative face want (negative face). The other face desire is that their personality be respected and their self-image be appreciated. This is called the positive face want (positive face). As such, every utterance has the potentiality of constituting a face-threatening act, either to the negative or positive face of individuals. And since, according to Brown and Levinson, many speech acts are naturally or inherently face-threatening, there is need for politeness to mitigate or redress the imports of face-threat inherent in them.

Thus, speech acts are performed along the lines of positive politeness, negative politeness, and off-record politeness. Positive politeness is geared towards supporting or enhancing an individual's positive face, while negative politeness is aimed at softening the encroachment on an individual's freedom of action or imposition. The off-record politeness revolves round flouting the Gricean (1975) maxims on the assumption that the addressee is able to infer the meaning intended. Usually in discursive interactions that involve the performance of face-threatening acts, the speaker decides whether to perform it or not. When the speaker decides to perform it, they can choose to do it directly or indirectly. When it is done directly, it is on record, but when done indirectly, it is regarded as off-record. When the speaker chooses to do it without any consideration for the hearer's face, it is done 'baldly', but when they choose to attempt to reduce the face-threatening effect to the hearer's face, they either deploy positive politeness or negative politeness.

Face threatening acts, an attack on the face of a hearer by a speaker, could come in form of abusing the hearer, encroaching the hearer's space, not attending to the request of the hearer, and condemning the action of the hearer, among others. The choice of whether or not to perform an FTA is the predicated on the weight or seriousness of the FTA. For instance, the speaker considers the degree (a culturally and situationally defined ranking of impositions by the degree to which they are considered to interfere with an agent's wants of self-determination or of approval, Brown and Levinson, 1987: 77) of the imposition associated with the FTA. Similarly, the speaker can consider the relative power of the hearer, defined as "the degree to which the hearer can impose his own plans and his own self-evaluation (face) at the expense of the speaker's plans and self-evaluation" (Brown \& Levinson, 1987).

According to Brown and Levinson (1987), "Face Threatening Act" comprises any speech act capable of constituting a threat to the positive or negative face of the hearer. Some of these include orders, suggestions, requests, warnings, disapproval, criticism, contradiction or threats to the speaker, thanking, minimizing hearers debt, transgression, apology, acceptance of compliment, and confession, among others. The schema below is a diagrammatic representation of the workings of the face act theory: 


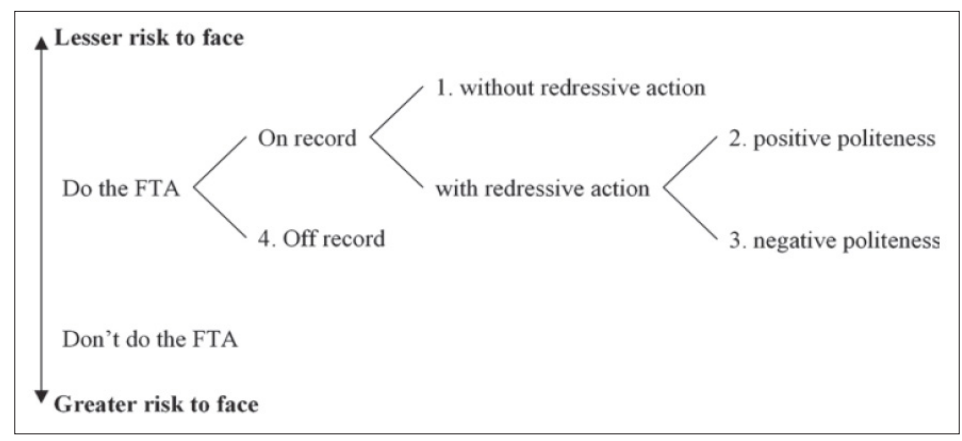

Fig. 1. Brown and Levinson's strategies for doing an FTA (1987, p. 69)

From the schema above, it is seen that performing the act bald on record is the most threatening strategy, while the least threatening linguistic strategy is performing the FTA off record (indirect performance). In between these two are on record FTAs, with or without redressive actions: positive politeness, with emphasis on positive face wants; or negative politeness, with emphasis on negative face wants. The adoption of face (act) theory in this study is predicated on the strategic use of face strategies by participants in Igbimo Ipetu discursive interaction to achieve certain pragmatic goals, aimed at achieving peace in the society.

\section{Research methodology}

The data for this study comprised four recorded editions of Igbimo Ipetu weekly aired on the Ekiti State Television with the primary aim of providing an alternative resolution to disputes among the people of the state. The four randomly sampled editions were representative of the ten editions, comprising fifteen cases initially recorded (after appropriate approvals have been sought and granted by the authorities of the station) between 2019 and 2020. The recorded sessions focused on cases such as land dispute among siblings, caretaker-tenant disagreement, disputes among members of social clubs/associations, and debt, among others. Data, comprising interactions mainly in the Yoruba language, being the official language of the programme, were transcribed into texts and appropriately translated into English. Data analysis was done within the purview of Brown and Levinson's $(1978,1987)$ face theory. However, for ethical purposes, the names of the various participants in the interactions were coded using letters from the English alphabet.

\section{Data presentation and analysis}

This section focuses on the discussion of the data for the study. In reference to the participants, the following codification is done: $\mathrm{M}$ represents the moderator (who contextually assumes the position of the judge in the interaction), J1 represents the first jurist, 
J2 represents the second jurist, while J3 represents the third jurist, ACC represents the accused and the COM represents the complainant. The various face acts observed are identified and discussed with relevant excerpts from the data.

\section{Bald on-record face-threatening act(s)}

Case 1: Loan and money issues

Background information: A woman reported the chairperson of a cooperative society to the panel.She applied for a loan but she was denied because her husband was accused of mismanagement of funds when he was the chairman of the association.

\section{Excerpt 1}

M: Báwo ni ẹ șe fẹ́ san owó obìnrin yìi?

How do you intend to pay this woman?

ACC: A máa fún un ní $\$ 6000$, ni oṣooșù....

We will paying her $\$ 6000$ monthly

M: ìgbàwo ni ó ma kan òhun báyìi?

When will it get to her turn to receive loan?

ACC: Ni oșù kejì ọdún ni ó ma rí owó naá gbà

She would get it in the second month of the year

M: (to COM) Sé ó tẹyín lọ́rùn?

Is that okay by you?

COM: (Nods in the affirmative)

M: (to the ACC): À màa retí yín ní oșù kejì ọdún o, nítorí ẹnu yín dùn báyî́ o, kìi șẹ pé kí o di ìgbà yẹn, kí e má wa sọ nǹkan mîl fún wa o. Nígbà yẹn, kì șe èyin àti òun mọ́ 0 . Ẹyin àti àwa ni.

We would be expecting you by the second month of the year; because your mouth is sugar-coated now and we won't want any excuse whatsoever by then. If you fail to comply, the issue will no longer be between the two of you but between you and us.

ACC: Àwa kì́ sọ̀rọ̀ ka má mu un sẹ.

We don't make empty promises.

M: Ọlọ́run nìkan ni asọ̀rọ̀máyẹ̀

It is only God that does not fail on His words. 
M: Eni tí o ni owó kò gbọdọ̀ pe egbẹ́, egbẹ́ náà kò gbọdọ pe àwọn èèyàn jọ fún ọ̀rọ̀ yî́. Kò gbọdọ sí ìfọ̀rọ̀ tami ọ̀rọ̀. Sé ẹ ti gbọ́ báyî́? Ó ti gbà nígbàtí òun náà mọ̀ pé àtènímónìi kò tó àtànámàná... Láti ònílọ, a à fẹ gbọ́ pé ẹ̀ ń fi lọ̀ káàkiri.

The complainant should never call the members of the club/association, neither should the club/association call any meeting over this issue. No exchange of words. Have you heard that? She has accepted, knowing the promised date is close. Henceforth, it should not be discussed with anyone.

Although a number of face strategies (as will be presented in subsequent excerpts) are employed in this excerpt, our focus is the use of bald on-record face-threatening act therein. From the interaction, it is obvious that the accused (ACC) has technically accepted the fact that her action of denying the complainant's request/application for loan, being a qualified member of the association who has the 'constitutional rights' to access such in line with the regulations of the association, is wrong and not acceptable. It is considered an infringement on the rights of the complainant to have acess to loan facilities as a bonafide member of the association. She then promises to redress the situation by ensuring the complainant is paid in installments. As a way of holding her by words and ensuring she lives up to expectation, the moderator (M) employs the bald on record face-threatening act to probe the promissory statement of ACC. In his words: 'À màa retí yín ní oṣù kejì odún o, nítorí ẹnu yín dùn báyií o, kií șe pé kí o di ìgbà yẹn, kí e má wa sọ nǹkan mi fún wa o. Nígbà yẹn, kií șe èyin àti òun mọ́ o. Èyin àti àwa $n i$ '. 'We would be expecting you by the second month of the year; because your mouth is sugar-coated now and we won't want any excuse whatsoever by then. If you fail to comply, the issue will no longer be between the two of you but between you and us'. This is a very serious face-threatening statement that subtly calls to question the integrity of ACC and one that is aimed at making her commit herself to the promise she has made.

The statement, when weighed on the scale of the principles of face-threatening acts of Brown and Levinson (1987), for instance, could be conceived as 'doubting the other' face-threatening act. Similarly, the subtle threat that should ACC fail to fulfil her promise, it would turn to be a matter between her and the panel is a face-threatening act meant to overwhelm her, ensuring that she does not fail to live by her words. Understanding this as a face-threatening statement, ACC attempts to 'repair' and project her positive face (that has been threatened by M) as a 'responsible' individual who keeps her promises and thus responds 'Àwa kî́ sộrọ ka má mú un sẹ'. We don't belong to the category of people who go back on their words', with the major aim of mitigating the face-damaging imports of M's statement. In reaction, M further threatens the positive face of ACC with a caveat or caution that it is only God that has the ability to keep to His words. This linguistic practice is strategically deployed to ensure ACC remains committed to her promise and to send a warning signal to her that failure to do as she has promised might attract serious consequences. Of course, the seriousness of the possible consequences of 
any breach of 'agreement' by ACC is jointly shared by M and her, based on their shared common ground on the power of the media possessed by M. The media is a powerful tool in creating positive and negative image for people, and since ACC would not want a negative image being created for her by the media, on whose platform $\mathrm{M}$ operates, she would want to do her best to fulfil her promise.

The use of bald on record face-thtreatening act also features in the concluding part of the excerpt where $M$ unmitigatedly gave standing instructions that restrain the activities of the two aggrieved parties, directing them not to call each other or discuss the matter with people henceforth. The statement constitutes a threat to the negative face of ACC (as well as other members of the association) and COM who have had their freedom to take further actions regarding the matter at hand restrained by the order of M. Although M, being a culturally competent speaker of Yoruba who understands linguistic diplomacy in the culture, knows the weight of his linguistic action (giving an order, especially to full-grown adults) as such that is face-threatening, he nonetheless chooses to go this way to prevent and foreclose the possible crises that might ensue between/among the aggrieved parties if left alone to go about the matter the way they want. This is done with the ultimate aim of achieving the overall goal of the exercise-ensuring peace among the individuals even after their grievances must have been settled.

Case 2: Rent, security and electricity bill issue

Background information: The complainant brought the case of a tenant that has allegedly owed rent for a year. The tenant (accused) allegedly insisted that he had spent the rent on room renovation. He (the tenant) also denied owning the security and electricity dues as claimed by the agent (complainant).

\section{Excerpt 2}

M: Șùgbón a ti yanjú rẹ̀.

... But we have resolved it

COM: owó ilé nìkan lẹsọ, ẹní ka wá lọjộ mẹjọ òní fún owó olọ́dẹ.

You only talked about the rent, and you told us to come for the security due as well next week

M: owó ilé nìkan ni a sọ, a nípé ẹ kî́ șe ọlọ́dẹ tàbí $\mathrm{BEDC}^{1}$, àti pé ilé tí à ń sọ yî́, ẹjọ́ ò bá șé e tò tí a bá rí landlord ilé yiî. Agent ni yín tí ẹ̀ ń bá èèyàn fa wàhálà...ẹ ń sọ̀rọ̀ owó ọộdẹ, owó iná, ẹyin dẹ̀ kọ́ ni ẹ ni ilé.

1 The electricity company that manages power distribution in Ekiti State. 
We are only resolving the rent matter because you are neither a security personnel nor a BEDC officer. This case would have been easily resolved if the landlord is here. You are just an agent that is troubling the tenant. You are requesting for security and $B E D C$ dues and you are not even the landlord.

J1: A sì sọ̀rọ̀ kan ní ọọo náà tí ẹ bá rántí, bí ẹ ti fa ọ̀rọ̀ yẹn kò yẹ kó rí bẹệ̀. Nítorí anfààní ni ẹ ní, ọkùnrin yẹn ní òun sàlàyé fún un yín irú ipò tí òun wà. Ẹ ripé a pa òwe kan ní ìjẹjọ yẹn tí ó bá jẹ́ Yorùbá ni yín.

We said something the other time, if you could remember. You have really dragged this matter beyond the necessary point. You are only privileged and the man explained his state of ill-health/condition to you. We made a proverbial statement last week if you a really Yoruba.

A critical appraisal of the interaction above reveals that the panel is not too pleased with the action of the complainant who claims the accused owes some debts which he must pay. While $\mathrm{M}$ is trying to assert his position that the whole issue has been resolved, COM insists not all the issues have been resolved as they (ACC and COM) have been asked to come the following week to clarify all other issues regarding other bills he claims ACC is owing. This counter-response to the submission of M that the whole issue has not been resolved is a bald on record face-threatening act that challenges his position (as the judge in the case). This linguistic behavior of ACC falls within the range of 'disagree with the other' face-threatening act of Brown and Levinson (1978, 1987). Not pleased with the subtle protest by COM, M consolidates on his initial bald on record face-threat to him (as presented in the initial part of the interaction as excerpt 1). He points to him no attention would be paid to the other bills mentioned by him (which amounts to 'ignore the interest of the other' face-threatening act). He further paints COM as a fellow usurping the powers of the landlord when he in actual fact is just a 'care-taker'. Another member of the panel, J1, further compounds the situation by telling $\mathrm{COM}$, without mincing words, that he just wants to take undue advantage of ACC, knowing full well he is 'helpless' in the situation, and particularly given his state of health (and perhaps low status relative to him). The import of the face-threat inherent in the response of J1 in particular would best be appreciated when contextualized within the Yoruba socio-cultural system. In the Yoruba culture, a lot of pragmatic goals are achieved through proverbs, including warning, correction, and encouragement, among others (see Odebunmi, 2008), and a typical Yoruba fellow is expected to relate to the contextual goal of the use of a particular proverb at a particular point in time or in a given context. That is one way of demonstrating cultural competence in the language and culture. Thus, his (J1's) statement 'if you are Yoruba, you would realize we made a proverbial statement in our last interaction' inferentially projects COM as a fellow who has not acted acceptably and as such should reconsider his position on the issue at hand. 


\section{Positive face (saving) act}

As discussed earlier, positive face revolves around the desire of a speaker to have his/ her personality respected and their self-image appreciated. The excerpts below manifest instances of the use of positive face strategy to achieve certain goals.

Case 3: Extra deduction of loan

Background information: A group of people brought the case of a man in charge of loan disbursement, who had been alleged of financial misappropriation. He had been called on several occasions but failed to appear before but finally showed up in this edition.

\section{Excerpt 3}

M: Alagba FF, e kaábọ o, a ti pe yin titi...

Welcome Mr. FF, it has been a while we have invited you

ACC: E sé olóòtú àti àwọn ìgbìmọ̀. Mo tọoọ àforíjì níwáju yín pé ó șe diệ kí n tó wá...ó jẹ́ kí n ní ìgbàgbọ́ nínú yín pé e kì í șe alágàbàgebè tàbí agbọ́-ẹnìkan-dájọ́...mo sì ri pé, è tò, è șe é sá tọ̀, tí e é sì bá wa yanjú ìșòro tí a bá wá bi.

Thank you, moderator and members of the panel. I am deeply sorry for coming later than expected...I have deep trust in you and that you are not hypocritical or biased in your adjudication... this programme is one that could help resolve any dispute brought before it.

M: E sé.

Thank you

In the opening part of the excerpt, M appeals to the positive face want of ACC by welcoming him on the program, despite failing to show up prior to this time. Perhaps this is done in acknowledgement of the fact that it is a 'privilege' that ACC has accepted the invitation of the panel as he is not under any legal obligation to appear before it. It is a general practice by the panel, especially as represented by $\mathrm{M}$, to welcome whoever is invited on the program, irrespective of the level of accusation against them. Having done this, he (M) then asks why it has taken long for ACC to respond to the invitation by the panel. In his response, ACC projects his own positive face, deploying the 'apologize to the other' positive face act/strategy to boost the ego of the members of the panel, by acknowledgeing the fact that not answering the invitation of the panel was not appropriate, but that it was not deliberate. This is in line with the Yoruba ideological proverb that 'ti elejo ba ti mo ejo re lebi, ki n pe lori ikunle' which translates as 'a fellow who has done something wrong acknowledges the fact that he has done wrong, such does not spend much time observing/serving punishment'. The fellow here, being a cultured Yoruba person, understands his action of not answering the invitation of the panel on 
time could be interpreted as a mark of disrespect, rudeness, and arrogance (a mark of face-threat to his positive face), and in order not to project himself as one (maintain his positive face), he resorts to apologies, to project his positive face and at the same time appeal to the positive face of the members of the panel. He also comments on the commendable efforts of the panel, describing it as a very reliable body whose members are upright and unbiased. All these are positive face acts/strategies by ACC to project his positive face as a good, responsible and cultured individual.

In acknowledgement of his 'good conduct' of apologizing for not appearing before the panel before now, M equally appeals to ACC's positive face with the appreciation statement 'thank you' which within the context of Brown and Levinson's theory would be regarded as 'appreciate the good deed of the other' face-saving act.

\subsection{Bald off-record face-threatening act}

The off-record FTA, according to Brown and Levinson (1987), is less face-threatening relative to the on-record FTA. In this instance, the speaker launches the face threat indirectly, without 'much overt pressure' on the hearer. However, our argument here is that, in the Yoruba interactional context, although off-record FTA could manifest in form of indirectness, it could not necessarily be regarded as less-threatening compared to the on-record FTA counterpart. This is because in the Yoruba language and culture, the full realization of the pragmatic import or weight of utterances is highly context-dependent. Thus, a statement might appear less offensive or face threatening linguistically, such can be highly face-damaging contextually. This is our argument in this section of the study.

Case 4: Sharing of Property/Land dispute

Background information: Mr. A brought the case of his elder brother that reportedly carried out a survey of their late father's landed property without his notice. He was particularly aggrieved his brother gave him less than he expected as his portion from the landed property and would want the panel to intervene.

\section{Excerpt 4}

M: Sé wọ́n fun yín níbẹ̀?

Were you given part of it?

COM: ...wộ́n fún mi ní 6 ... ó wá kó 16 plots. È mi ò sì lè gbà yẹn.

I was given 6...he took 16 plots. I cannot accept that

COM: ... ìyàwó mẹ́ta ni bàbá wá fẹ́, șùgbón ìyàwó kẹ́ta kò bímọ. Sé ẹ mò pé kó ní ní nǹkankan. 
Our father married three wives, but the third wife did not give birth to any child. You know she won't have any share.

M: ìyàwó kẹta yẹn kò ní ní nǹkankan bẹ́yẹn?

The third wife won't have any share?

COM: Bẹeẹni, kò bímọ kankan.

Yes, she didn't give birth to any child

M: Sé iyàwó kẹ́ta wà láàyè?

Is the third wife still alive?

COM: Béèni

Yes

M: kò dẹ ní ní nǹkankan? Ehn ehn.

And she won't have any share? Really!

J1: Ǹjẹe ẹ ti gbọ ìdí igi rí? Obìnrin ní ó ń jệ ìdí igi.

Have you heard of family root before? It is the woman that is being referred to as family root.

COM: Bí wọ́n șe máá ń sọ̀ ní yẹn, pé obìnrin tí kò bá bí mo, kò ní nǹkankan ní ilé ọkọ rẹ̀. That is how it is the general notion that a woman that has no child has nothing in her husband's house.

In the excerpt above, in making his case, COM explains that their late father had three wives out of whom one did not give birth. Meanwhile the elder brother, the ACC, had earlier hinted that it was impossible for COM to have more than he had got because some of the landed property should also naturally go to the woman in question even though their late father did not have any child by her. Contrary to this position, COM argues that it is customary in the Yoruba socio-cultural setting not to bequeath any property to a wife who does not have children for her husband while alive. It is on account of this 'ideological' ground that he wants what should go to their late father's childless wife as her share of her late husband's property, to be given to him as part of his share. This idea does not go down well with the members of the panel who resort to the deployment of off-record FTA to criticize the unkind stance of COM. For instance, the questions asked by M in reaction/response to his argument: 'ìyàwó kẹta yẹn kò ní ní nǹkankan bẹyẹn?, sé ìàwó kẹta wà láàyè? Kò dẹ ní ní ṅkankan?ehnehn', 'The third wife won't have any share?, Is the third wife still alive, And she won't have any share? Really!' constitutes off-record FTAs that indirectly query, condemn and criticize the position of COM. Following the arguments of Ajayi (2018), for instance, these questions are instances of the use of verbal indirection aimed at attacking the face of COM in this very instance. The questions are loaded expressions that raise a very big question on how 
much of sense of humanity is possessed by COM for him to feel the woman should not be apportioned any property because of her childlessness status. The logic is, how would he claim a woman who is married to their father, a bonafide member of the family, and who is still very much alive, is not entitled to any part of her late husband's property on account of her not giving birth? The use of discourse marker 'ehn ehn', which could be contextually deconstructed as 'really!' by M to emphasize his indirect condemnation and mockery of the 'inhuman and inhumane' arguments by COM is, instructive. Its use in the discourse signals 'what you are saying does not make any sense'.

To further reinforce the position of $\mathrm{M}, \mathrm{J1}$, also raises another question which constitutes an off-record FTA meant to attack the face of COM: ǹjé ẹti gbo ìdí igi rí? Obìnrin ní ó ń jẹ ìdí igi 'Have you heard of 'the root of the tree ${ }^{2 '}$ before? It is women that are being referred to as the root of the tree'. Embedded in this question by J1 are condemnations and rejection of COM's argument. In particular, J1 indirectly knocks out the argument of COM that 'a woman who does not have children for her husband is not entitled to her late husband's property' by emphasizing through her question which logically suggests the woman is the symbolic entity that represents herself and her children in the family. This is why she makes reference to the notion of ìdí igi in her question. In the Yoruba socio-cultural context where polygamy is culturally acceptable, it is the practice to have sub-families within the family. As such, each wife of a polygamous man is seen as the 'head' or 'reference point' of each sub-family within the entire family. And whenever there is a development in the family that requires 'sharing' or distribution of resources, responsibilities, and particularly of property, it is done on the basis of the number of wives; the wives being regarded as the 'tree/vine' while the children are the 'branches'. This practice is what J1 makes reference to in her question which indirectly berates COM.

\section{Excerpt 2 (Continuation of 4)}

M: ...ó șeéșe kí ó jẹe irú ìdájộ yiî kọo ní ẹ̀gbọ́n yín șẹ báyîi. Bóyá òun ti fún wọn ní nǹkan. ...it is possible your brother might not give the same judgment as yours, maybe he gave her something already

COM: kò fún wọn ooo.

He did not give them

M: ...kí ni orúkọ è?

What is his name?

COM: Mr XXX, bàbá Xxx, Xxy àti Yyy

Mr XXX, the father of TTT, UUU and PPP

2 This is a sort of metaphoric expression in Yoruba that compares the woman to the tree while her children her conceived as branches. So in order of importance, it is the tree first before its branches. 
M: kí ni orúkọ àwọn ọmọ tì ẹ?

What are the names of your own children?

COM: Ehmm, ZZZZ

Ehmm, ZZZZ

M: Ó rántí orúkọ mẹ́ta nínú orúkọ àwọn ọmọ ẹggbọ́n ẹ̀, kò rántí orúkọ ọmọ ti ẹ̀ He could remember three names of his brother's children but could not remember his children's names

J1: Ó need ògùn ìsòyè.

He needs an elixir for memory resuscitation

J3: ...Ah! àwọn ọkùnrin méjì bale ilé.

Imagine! Two full-grown men

In excerpt 2 of Case 4 , as presented above, the off-record FTA equally manifests. For instance, when asked to mention his brother's and children's names, he (COM) could remember; but when asked his own children's names, he demonstrates brief memory loss (perhaps deliberate to save the face of his children by not mentioning them in the interaction), trying to remember. The members of the panel find this a bit awkwardly strange and comment on it, albeit indirectly. For example, M comments 'you remember the names of the three children of your brother but you could not remember the names of your own child(ren). In addition, J1 comments 'ó need ògùn ìsòyè', he needs an elixir for memory boost. Contextually and culturally speaking, these statements by $\mathrm{M}$ and J1 are pragmatically loaded. They are statements that indirectly query the kind of father he (COM) is; if he could remember the names of his brother whom he has come to report and his children's but could not remember his own children's names. What this suggests is that he is a careless, nonchalant and materialistic fellow who is much more interested in material acquisition than in his children. In the Yoruba culture, it is ideologically believed that children are very important and that the height of one's achievements is having a child or children. This explains why parents are expected to take care of their children and know them intimately. The intimacy should be such that a responsible father or parent would readily remember the name(s) of his/their children even if they are being asked 'in their sleep'. Not being able to readily provide the names of his children in this interaction already casts an atmosphere of doubt on the serious-mindedness of COM, and M and J1's responses/reactions to this show this is not acceptable, hence condemnable. In addition, what can be more insulting than recommending an elixir for a father in order for him to remember the names of his child(ren)? Our argument here thus, is that, instead of $\mathrm{M}$ and J1 openly or directly calling COM a daft, an unserious-minded and materialistic fellow, which could be overtly face-damaging, they resort to the off-record FTA strategy, knowing 
the possible effect the use of those on-record FTAs could have on the overall atmosphere of the interaction.

Similarly, the comment of $\mathrm{J} 3$, though appears linguistically short and simple, is highly face-damaging for anyone that understands the workings of the Yoruba culture. In the comment, J3 makes reference to the word 'baálé ile' 'the king/head of the house' to indirectly attack the positive face of both COM and ACC (although not physically present), projecting them as not being 'responsible' men indeed. This becomes obvious when the semantic nuance of the phrase 'baálé ilé' is explored in the Yoruba socio-cultural context. In Yoruba, 'baálé ilé' is seen as the head/king of the house. As such, he is expected to be mature, responsible, and must be natively intelligent enough to be able to manage situations such that they do not degenerate into full-blown crises. Thus, in the estimation of J3 here, the two men at the centre of the discourse are not 'kings/ heads' indeed of their respective homes'. As could be deduced from his statement, if they were indeed capable of managing situations in their respective homes, it would not have been difficult for them to address the situation at hand before degenerating into a serious crisis they now have. Thus, the exclamatory statement: 'Ah! àwọn okùnrin méjì bale ilé.' Ah, two full-grown married men' indirectly suggests the two men are real men, fathers and husbands, expected to demonstrate wisdom, maturity and shrewdness in handling situations. This typifies such instances of language use in Yoruba where linguistic expressions appear únharmful and benign on the surface but are contextually or situationally face-damaging.

\section{Conclusion and remarks}

This study attempts an investigation of face acts (otherwise occasionally referred to as face strategy) in alternative dispute resolution television program in southwestern Nigeria, with particular reference to Igbimo Ipetu, aired on Ekiti State Television, Ado Ekiti, Nigeria. The study, departing from the thematic focus of previous works such as Ogwuche (2016), Oyedele (2016), and Ajayi (2017), which have extensively explored phenomena such as discourse structure, language use in alternative dispute resolution television programs in southwestern Nigeria, focuses mainly on face acts and their pragmatic functions in such program, with particular reference to Igbimo Ipetu. Data, which comprised four purposively sampled recorded editions of Igbimo Ipetu transmitted between 2019 and 2020, were analyzed using Brown and Levinson's (1987) face theory. From the findings, it becomes clear that different face acts/strategies are used for different pragmatic goals in the interaction. For instance, the bald on-record and bald off-record face-threatening acts are used by members of the panel to criticize, condemn, berate and correct actions considered unacceptable and condemnable, either on the part of the complainant or the accused. The bald on-record face-threatening act is also deployed by complainants or accused persons to subtly 
protest the position of the panel not considered favorable. The positive face act is deployed by the accused to appeal to the positive face of the members of the panel in order to negotiate a 'soft treatment' in the interaction, while the panel employs the same strategy to create a somewhat relaxed atmosphere for the accused, especially when such appears cooperative. All these face strategies and counter-strategies are deployed by the participants in the discourse with the ultimate aim of repairing estranged relationships among/between the aggrieved parties, which is the major purpose of alternative dispute resolution exercise, as opposed to the western litigation system. Also, from the theoretical perspective, the study demonstrates the fact that a statement/uttreance that is linguistically less face-threatening and as such categorised as an instance of off-record face-threatening act (following the argument of Brown and Levinson, 1978, 1987) could actually be as contextually face-damaging/threatening as an on-record face-threatening statement. That is the case in Yoruba. Thus, the study upholds the positions of scholars like Watts (2003), Arundale (2009), and Ajayi (2018), for instance that although the notion of face is a universal phenomenon, its workings are context or culture-specific.

\section{References}

1. Ajayi, A. T., \& Buhari, L. O. (2014). Methods of conflict resolution in African traditional society. African Research Review, 8(2), 138-157.

2. Ajayi, T. M. (2017). Ọmọlúàbí and discourse strategies in Yoruba conflict resolution television interaction in Nigeria: A case study of Sódáabẹẹ. Coaxial Journal of Linguistics Studies, 2(1), 29-62.

3. Ajayi, T. M. (2018). An ethno-pragmatic analysis of verbal indirection in Yoruba. Jurnal Arbitrer, 5(2), 67-74.

4. Arundale, B. R. (2009). Constituting face in conversation: face, facework, and interactional achievement. Journal of Pragmatics, 42, 2078-2105.

5. Black, H. C. (2009). Black's Law Dictionary. West Publishing.

6. Brown, P., \& Levinson, S. C. (1978). Universals of language usage: Politeness phenomena. In E. Goody (Ed.), Questions and politeness (pp. 256-289). Cambridge University Press.

7. Brown, P., \& Levinson, S. C. (1987). Politeness: Some universals in language usage. Cambridge: Cambridge University Press.

8. Brock-Utne, B. (2001). Indigenous conflict resolution in Africa. A draft presented to weekend seminar on indigenous solutions to conflicts held at the University of Oslo, Institute of Educational Research.

9. Goffman, E. (1967). Interaction ritual: Essay on face to face behavior. Anchor.

10. Gould, N. (1999). Dispute Resolution in the construction industry: processes, perceptions and predictions. International Construction law Review, 16(4), 574-587.

11. Grice, H. P. (1975). Logic and conversation. In P. Cole \& J. Morgan (Eds.), Syntax and semantics (pp. 41-58). Academic Press. 
12. Hobbs, P. (2003). The medium is the message: Politeness strategies in men's and women's voice mail messages. Journal of Pragmatics, 35, 243-262.

13. Ige, A. Y. (2017). Alternative dispute resolution and collective conciliation in Nigeria: A review of contemporary literature. International Journal of Business and Management, 12(8), 261-271.

14. Iseh, K. (2020). Alternative dispute resolution: revisiting the approaches for conflict settlement in Nigeria. SSRN. Doi: http://dx.doi.org/10.2139/ssrn.3544150.

15. Ji, S. (2000). 'Face' and polite verbal behaviors in Chinese culture. Journal of Pragmatics, 32(7), 1059-1062.

16. Lucille, M. P., \& Cavenagh, T. D. (1991). Alternative dispute resolution in business. West Educational Publishing Company.

17. Matawal, M. E. (2018). The role of media in conflict managementnt: A case study of Jos North Local Government Area of Plateau State. A BA dissertation defended at the National Open University, Nigeria.

18. Nwazi, J. (2017). Assessing the efficacy of alternative dispute resolution (ADR) in the settlement of environmental disputes in the Niger Delta Region of Nigeria. Journal of Law and Conflict Resolution, 9(3), 26-41.

19. Odebunmi, A. (2008). Pragmatic functions of crisis-motivated proverbs in Ola Rotimi's The Gods Are Not to Blame. Linguistik online, 33(1), 73-84.

20. Ogwuche, D. A. (2016). Discourse strategies in conflict resolution in the Yoruba socio-cultural system: A case study of Ijoko-Ojogbon. A BA dissertation defended at the Department of Linguistics and African Languages, University of Ibadan, Nigeria.

21. Olaoba, O.B. (2001). An introduction to Africa legal culture. Hope Publications.

22. Oyedele, R. (2016). Face management strategies in conflict resolution in Yoruba: A case study of Mogbejomidé. A BA dissertation defended at the Department of Linguistics and African Languages, University of Ibadan, Nigeria.

23. Oni-Ojo, E. E., \& Roland-Otaru, C. (2013). Alternative dispute resolution strategies for sustainable development in Africa: Insights from Nigeria. Journal of Management and Entrepreneurial Development, 3(1), 37-54.

24. Orji, U. J. (2012). Technology mediated dispute resolution: Challenges and opportunities for dispute resolution. Computer and Telecommunications Law Review, 5, 125-133.

25. Sadeghoghli, H., \& Niroomand, M. (2016). Theories on politeness by focusing on Brown and Levinson's politeness theory. International Journal of Educational Investigations, 3(2), 26-39.

26. Schwartz, S. L. (n.d). Alternative dispute resolution: A strategy for combining profit and principle in Resolving business conflicts. Retrieved from https://www.mediate. com/adrsolutions/docs/Published\%20format\%20ADR-Article-Schwartz_format ted[1]3-14-07.pdf.

27. Uzuegbunam, C. E., \& Omenugha, N. O. (2018). Mainstream media, social media and peace-building in Nigeria: Old challenges, new opportunities? The Nigerian Journal of Communication (TNJC), 15(2), 519-534. 
28. Watts, R. J. (2003). Politeness. Cambridge University Press.

29. Yates, D. (2003). Can claims and disputes (in construction contracts) be prevented or reduced?. Building Journal Hong Kong China. Retrieved from http://www.building.com. hk/forum/10_03canclaims.pdf. 